\title{
The Responsibility to Protect in a World of Already Existing Intervention
}

Dr Robin Dunford, University of Brighton: Rfd10@brighton.ac.uk

Dr Michael Neu, University of Brighton: M.Neu@brighton.ac.uk

\begin{abstract}
:
In the face of humanitarian crises, members of the international community are often presented with a choice: engage in forms of action including military intervention, or stand by and watch. This framing ignores practices of intervention that are already taking place and contributing to the emergence and perpetuation of humanitarian crises. Despite calling for more attention to be paid to already existing intervention, literature on the Responsibility to Protect (R2P) has not adequately understood its implications for the legitimacy and likely effectiveness of military intervention. To redress this gap, we argue, first, that focus on already existing intervention complicates the moral calculus on which defences of military intervention as part of the R2P are based. Second, we claim that actors already engaged in damaging practices of intervention are bad international citizens who are not fit for the purpose of humanitarian military intervention. Third, we argue that in both ignoring already existing intervention and calling for additional military intervention under its third pillar, the R2P legitimises a moralistic form of militarism. These three arguments show that it is a mistake to follow recent literature (Brown and Bohm, 2016; Souter, 2016) in responding to already existing intervention by simply adding to the R2P, for instance, duties to engage in structural prevention and to support refugees. What is needed, rather, is a more fundamental rethink that departs from the R2P.
\end{abstract}

Keywords:

Responsibility to Protect, Humanitarian Intervention, Mass Atrocity, Militarism, Good International Citizenship, Jus ad Bellum

Acknowledgements:

Two anonymous referees and the editorial team of the European Journal of International Relations offered sharp and insightful comments, which have helped improve the article. We would also like to thank Dr James Souter for his comments on a prior draft. Finally, we would like to thank Dr Cathy Bergin, Professor Bob Brecher, Dr Vicky Margree and Professor Mark McGovern, whose comments have helped shape our argument. Any remaining errors are our own.

\section{Author Bios:}

Robin Dunford and Michael Neu are both members of the Centre for Applied Philosophy, Politics and Ethics at the University of Brighton. Their forthcoming book, Just War and the Responsibility to Protect: A Critique, will be published by Zed Books in 2019. 


\section{The Responsibility to Protect in a World of Already Existing Intervention}

Amidst reports of a chemical weapons attack carried out by the Assad regime in Douma, there arose a familiar call for the international community, and "the West" in particular, to "do something”. 'It is just not good enough to say that there is nothing the West can do in the face of mass murder', wrote Simon Tisdall (2018); 'after Douma, the West's response to the Syrian regime must be military'. This was but the latest in a long line of calls for the international community to stop its 'hand-wringing' and to step up and "act” (Simpson, 2016). The crisis in Syria, Conservative member of the House of Commons George Osborne (in Wintour, 2016) had said over one year earlier, was 'created by a vacuum, a vacuum of western leadership, of American leadership, British leadership'. The crisis highlights, he continued, 'the price of not intervening'. Osborne's words are reflective of the broader way in which mass atrocity situations - and suitable responses to them - are framed in public discourse and in writing on the Responsibility to Protect (R2P) - the international commitment to prevent and respond to mass atrocity crimes of genocide, ethnic cleansing, war crimes and crimes against humanity. It is a framing that imagines that crises like Syria simply crop up. The "international community", previously un-involved, then faces a choice: “act” - often a euphemism for engaging militarily - or "stand aside" and watch the crisis unfold.

What this framing ignores is the large extent of intervention that is already occurring, including international monetary intervention, activity that degrades the environment, and attempts to stoke ethnic tension. These practices of intervention not only result in an everyday atrocity of mass avoidable death and suffering through hunger, poverty, ill-health and pollution. They are also conducive to the emergence of the humanitarian crises that the R2P seeks to address. In this paper, we argue that existing literature has not adequately recognised the implications that already existing intervention has for the legitimacy and likely effectiveness of military intervention. As a result, it is not clear whether those who contribute to the emergence of atrocity crimes through their non-military interventions have additional duties of military intervention (Fabre, 2012), whether they ought to engage in humanitarian disintervention (Nili, 2011), or whether already existing intervention has different implications still (Brown and Bohm, 2016). 
To fill this gap, we make three arguments. First, focus on everyday atrocity and already existing intervention complicates the moral calculus on which defences of military intervention as part of the R2P are based. Second, we claim that actors already engaged in damaging practices of intervention are bad international citizens who are not fit for the purpose of pillar three military intervention. States that fail to meet both negative duties to cease from harmful practices and positive duties that can be fulfilled without the use of harmful military means are not 'good international citizens' (Souter, 2016) whose interventions are likely to result in good humanitarian outcomes. The track record of such actors in engaging in inhumanitarian and unprotective action in Libya and elsewhere, far from being an aberration to be corrected as "protectors” learn through experience and as state interests are increasingly reconciled with humanitarian values, is to be expected on the basis of the kind of actors that the intervening states are. Third, we claim that in both ignoring already existing intervention and calling for additional military intervention under its third pillar, the R2P works to legitimise a moralistic form of militarism. It contributes to a moral climate in which war is framed in a particular way - as humanitarian, civilised, laudable and virtuous. This climate is characterised by an amnesia about the deeper structural causes of mass atrocity; about the way in which purported humanitarian saviours are heavily implicated in the constant reproduction of these causes; and about the fact that wars waged by these bad international citizens are unlikely to be effective and legitimate. If our arguments are correct, the R2P is emphatically not the 'the best chance in our own time to build an international community that is less tolerant of mass atrocities and more predisposed for preventing them' (Bellamy, 2015, 1). Nor will it 'end mass atrocities once and for all' (Evans, 2009, 2). Rather, it is a dangerous norm, and alternatives are required if we are to respond adequately to the call for no more Rwanda's.

\section{Already existing Intervention and Everyday Atrocity}

Calls for international actors to stop "standing aside" and "do something” in the face of genocide, war crimes, crimes against humanity and ethnic cleansing are all too familiar. International actors are presented either as passive ‘bystanders to genocide’ (Power, 2001), or as humanitarian saviours who step up and “act”. In Libya, the international community was praised for deploying 'international force to neutralise the military might of a thug and intervene between him and his victim', whilst in Syria, accusations of hand-wringing continue (Thakur, 2013, 69; see also Luck, 2011, 394). This dichotomy assumes that would-be interveners 'bear no responsibility for the injustice at hand: someone else is committing 
shameful acts; we are merely considering whether or not we have a positive duty to do something about it' (Nili, 2011, 33; see also Orford, 1997). Despite the intention of the architects of R2P to avoid this framing of atrocity by focusing on a wider array of preventive measures and forms of international assistance, the sense that would-be interveners bear no responsibility for humanitarian crises remains (Whyte, 2017; Brown \& Bohm, 2016).

The first pillar of the R2P, according to which state sovereignty is a responsibility to protect people in the state's territory from genocide, war crimes, ethnic cleansing and crimes against humanity, 'responsibilises' individual states for crises that happen within them; the presumption is that their actions or lack of capacity will be at the root of any problems (Whyte, 2017, 310). Even under pillar two, on international assistance, capacity-building and prevention, the R2P 'locates the blame for crises with the government of the state that is perceived to be unable or unwilling to protect its population, providing for the "international community" of willing states to exercise a secondary ... responsibility towards distant strangers’ (Brown and Bohm, 2016, 909). Then UN Secretary General Ban Ki-Moon’s report on international assistance and the R2P, for example, focuses on building domestic capacity, providing encouragement and offering protection assistance. Domestic capacity might be built through the creation of: an 'accountable security sector; impartial institutions for overseeing political transitions; independent judicial and Human Rights institutions; the capacity to assess risk and mobilise early response; local capacity; media capacity; and capacity for effective and legitimate transitional justice’ (UN, 2015, footnote 20; UN, 2014). Similarly, international encouragement might involve peer review of activities and prevention mechanisms in a vulnerable state, 'awareness raising and norm dissemination', 'the dissemination of human rights and humanitarian standards and norms', the 'education of national authorities', and 'confidential or public dialogue to remind states under stress of the importance of meeting their responsibility to protect' (UN, 2014, 29-31). All of these relate to problems that exist over there, in the state in question. Even as it focuses on additional forms of international support, the R2P therefore does not bring into the picture potentially damaging practices of intervention that exist already. Members of the "international community" continue to be presented as helpers or bystanders, and not as potential contributors to humanitarian crises. We use the term "already existing intervention" in order to escape this binary according to which the international community either acts by “intervening” or fails to act by "standing aside”. To this end, the term refers very broadly to actions - taken by foreign states, multinational corporations, international organisations, and/or other actors operating across borders - that contribute to the emergence of atrocity crimes. ${ }^{i}$ 
The R2P also ignores everyday atrocity. This is because it is, according to Moon (UN, 2014, paragraph 79), 'narrow but deep: narrow because it is restricted to the protection of populations from atrocity crimes [genocide, war crimes, ethnic cleansing, and crimes against humanity], but deep given the array of measures required for its implementation'. What this narrow focus ignores is the atrocity of mass avoidable death and suffering that takes place as a matter of routine. In the Rwanda genocide, around 800,000 people were killed in one hundred days. A person dies for hunger-related reasons every 10 seconds, meaning that even more people die as a result of hunger every 100 days. ${ }^{\text {ii }}$ Factoring in other avoidable deaths, the picture is even bleaker. In 2015, more than 16,000 children aged under five died every day. According to the World Health Organization, 'almost all of these children's lives could be saved if they had access to simple and affordable interventions' (WHO, 2017). And environmental decline is already a mass killer, especially in low-income countries. Using World Health Organization Data, the Lancet Commission on Public Health (Landrigan, 2018) found that pollution alone currently kills nine million people per year; almost 25,000 people per day. This figure is, according to the co-lead of the commission, 'almost certainly an under-estimate, probably by several million' (cited in Carrington, 2017).

These deaths are not a mere accident, nor are they unavoidable. They are produced politically, in part by the actions of the "international community". Given that our primary focus is on the as yet under-explored implications of already existing intervention for humanitarian military intervention under the R2P, we do not have space to repeat accounts of how international interventions contribute to this everyday atrocity (i.e., Anievas and Nişancıoğlu, 2016; Dunford and Neu, 2019, 59-93; Galeano, 1997; Hickel, 2017). But to give a very brief picture, environmental decline is actively produced, in particular by wealthier countries. Moreover, whilst substantial resources go from global North to global South through aid, these numbers are dwarfed by flows that go in the opposite direction through what Jason Hickel (2013) calls ‘aid in reverse’. According to data from Global Financial Integrity (2015) and the Centre for Applied Research at the Norwegian School of Economics, in 2012, \$2 trillion moved from developed countries to developing countries through foreign investment, aid, trade, debt cancellation, remittances and capital flight. Far more - \$5 trillion - went in the other direction through payments on debt, capital flight and other means. While these mechanisms may not always involve the stark direct physical violence of colonial rule, it continues to be the case that a world of radically unequal life chances is 'actively created', in part through the actions and omissions of actors such as transnational corporations, foreign governments and international organisations (Hickel, 2013). 
Why do everyday atrocity and the already existing interventions that co-produce it matter for the R2P? They matter not only because, as we shall argue later, they fundamentally change the question of when military intervention is legitimate and likely to be effective. They matter also because, as Brown and Bohm (2016, 903) point out, they create conditions conducive to the occurrence of mass atrocity crimes. Low levels of economic development are a major risk factor for civil conflict and for atrocity crimes that occur therein (Collier et al., 2003). Links have also been found between environmental change and conflict, including the ethnic cleansing in Darfur that elicited calls for humanitarian military intervention (Moon, 2007). This is before we investigate arms trading and attempts to stoke ethnic tension. Having been used as a strategy of colonial rule, attempts to divide different ethnic groups have left a huge legacy in the form of conflict in sub-Saharan Africa (Boone, 2014). They continue today, having been rife for a decade in Syria. Wikileaks cables from 2006 showed that the US were considering attempts to foment Shia-Sunni tensions by playing 'on Sunni fears of Iranian influence' (Naiman, 2015). Moreover, a 2008 US army funded RAND (2008, xvi) report suggested that the US might use 'covert action, information operations, unconventional warfare' and other means to 'capitalise on the sustained Shia-Sunni conflict trajectory by taking the side of the conservative Sunni regimes against Shiite empowerment in the Muslim world ... possibly supporting Sunni governments against a continuingly hostile Iran'. In terms of arms trading, as genocide unfolded in Rwanda, the international community "stood aside" to watch weapons provided by some of its members getting turned on civilians. Between 1990 and 1994, the Rwandan state spent $70 \%$ of its budget - including some of the loans it received from the World Bank - on arms (Fruchart et al, 2007). The biggest supplier by far was France. Moreover, when the United Kingdom intervened in Libya, it did so one year after increasing arms exports to Libya by a factor of ten, and less than two months after signing off a license for the unlimited export of military communications equipment (Guardian, 2011; CAAT, 2013). This should perhaps come as no surprise. After all, Campaign Against the Arms Trade (2017) reports that of the 28 countries the UK government identified as countries of concern in a 2014-5 human rights and democracy report, it approved arms export licenses to 18 . When Ramesh Thakur $(2013,62)$, one of the members of the International Commission on Intervention and State Sovereignty (ICISS) report that introduced R2P, suggests that the 'the principle ... is an acknowledgement by all who live in zones of safety of a duty of care towards those in zones of danger', we should remember that the provision of weapons from the supposedly separate safe zones facilitates the very barbarism in 'zones of danger' that elicits pleas for action. 
Already existing intervention stokes the crises to which the R2P responds. It is partially responsible for 'the current disorder and violence in those states now targeted for Western intervention' (Whyte, 2017, 310). Thus, 'many of the same powers that ultimately send in the troops have often played a significant role in creating conditions ripe for a crisis’ (Engle, 2007, 224). In ignoring everyday atrocity, and the already existing practices of intervention that reproduce it, the ' $\mathrm{R} 2 \mathrm{P}$ perpetuates the same mistakes of the humanitarian intervention debate, overlooking the international community's involvement in the intrinsic injustices operating at the systemic level, which themselves contribute to the outbreaks of violence to which the R2P seeks to respond' (Brown and Bohm, 2016, 910).

Despite exposing these problems, critical literature on the R2P has not offered a satisfactory analysis of the implications of already existing intervention for defences of pillar three intervention. It has helped expose the persistence of gendered and colonial narratives in R2P (Charlesworth, 2010; Engle, 2007; Mamdani, 2010; Pourmokhtari, 2013; Whyte; 2017). It has also demonstrated a need for richer understandings of prevention (Brown and Bohm, 2016) and of the peaceful alternatives to military intervention that are hidden from view when already existing intervention and everyday atrocity are ignored (Charlesworth, 2010; Heathcote, 2014). But a series of questions remain: is the appropriate response simply to add, under pillar two, an additional focus on deeper, structural prevention measures? Or does focus on already existing intervention change how we ought to think about the legitimacy and likely effectiveness of pillar three humanitarian military intervention? If so, does it suggest that what is called for is not intervention, but, rather, disintervention (Nili, 2011)? Or should it lead to calls - made by Fabre (2012, 178-192) - for actors that are already intervening to intervene even more, on the grounds that they have special duties that arise from their prior (and ongoing) wrongdoing?

For Brown and Bohm (2016, 897), failure to focus on already existing intervention renders R2P 'insufficient' and 'incomplete'. What is required is the addition of principles of Jus ante Bellum (Right before War). 'If ... there is a strong duty to kill in order to save victims of direct violence', Brown and Bohm (2016, 902) argue, 'then there must also be a strong duty to prevent conflict from happening in the first place'. '[T]he fulfilment of this duty will', in turn 'require additionally robust commitments to global distributive justice'. The overall approach, here, is one of highlighting additional commitments - to addressing everyday atrocity through global distributive justice, and to changing practices of intervention that stoke conflict. Just ante Bellum serves not to introduce criteria - of ceasing arms sales, redistributing wealth globally, cutting negative impacts on the environment, and so on - that must be met 
before the legitimacy of military intervention is even considered. Rather, it serves to 'justify the ultimate aim of these [military] interventions in the face of growing criticism', including criticism from those who consider military intervention and cosmopolitanism more broadly 'as a form of imperialism' (Brown and Bohm, 2016, 898; 915). Brown and Bohm also appear to endorse Fabre's $(2012,181)$ argument that additional duties of intervention emerge where the intervening party 'is under a duty because it is in part responsible for the predicament in which target parties find themselves'. Once again, they add an additional commitment, saying that if the responsibility for a crisis relates not to direct arms sales between the would-be intervenor and the state intervened in but, rather, to structural inequalities, responsibility should be assigned to those who perpetuate and benefit from these structural conditions. Jus ante Bellum therefore 'plays two important normative roles'. First, it adds a richer focus on prevention; it 'helps us reflect more clearly about what conditions need to exist (or have existed that should not) in order to alleviate the underlying structural causes that help to perpetuate or escalate humanitarian violence in the first place'. Second, it 'provides a heuristic tool to help think about how to assign responsibility' (Brown and Bohm, 2016, 907). Responsibility - to address structural causes and to intervene militarily - falls on those who have contributed to the situation. What Jus ante Bellum does not do, however, is rethink more fundamentally the legitimacy and likely effectiveness of pillar three intervention.

Where Brown and Bohm call for additional action, Nili $(2011$, 39) claims that 'disintervention is logically prior to intervention'. This claim is based on the presumed priority of negative duties to cease from harmful practices over positive duties to provide assistance. But even if Nili $(2011,39)$ is right to suggest that 'it is very hard to deny that negative duties are even weightier' than 'positive duties to aid and protect others who are in severe distress', it is not clear why extra weight equates to logical and temporal priority. Moreover, it is not true to say, as Nili $(2011,35)$ does, that 'no one in their right mind would appeal to someone who is currently harming them for protection'. In desperate situations when groups are at risk of being subjected to genocide, for example, their plea to be rescued even by those who sold the weapons with which the genocide is being carried out may be quite understandable. Moreover, Nili suggests that duties are even greater for those who bear responsibility for the occurrence of humanitarian crises: 'while your duty to save a drowning child at a negligible cost to yourself ... might be a powerful one, your duty to save a child that you pushed into the water yourself (even if you did so with others) is clearly even more pressing' (Nili, 2011, 39). Precisely this example, however, is commonly used to justify military intervention by parties who, through their already existing interventions, have co-produced the conflict at hand. Take Fabre (2012, 
189), who claims that one would not forbid a murderer from saving a drowning child simply on account that they are a murderer. 'What matters, rather, is that he should be able to swim and rescue the child effectively - and then hand her over to appropriate parties.' Indeed, when reflecting on the fact that France was still providing weapons to Rwanda 'as the massacres had already started', Fabre $(2012,190)$ postulates that 'it might stand to reason that France had a primary responsibility to intervene in the genocide as early as April 1994 - just as it behoves me, out of all available rescuers, to help the child I negligently pushed into the water'. Thus, whilst Nili does recognise that already existing intervention has significance, he provides insufficient grounds to demonstrate that we should call for humanitarian disintervention, rather than special, compensatory duties of humanitarian military intervention.

The implications that already existing intervention and everyday atrocity have for military intervention therefore remain unclear. In what follows, we draw out three such implications. Together, the following sections serve to show that in the context of everyday atrocity and already existing intervention, pillar three military intervention is neither legitimate nor likely to be effective.

\section{Increasing the "Pool of Protection” in a World of Everyday Atrocity}

Two key elements of the moral defence of pillar three intervention are proportionality and prospects for success. Given that military interventions kill innocent people and result in displacement, sexual violence and other rights violations, they must be justified on the basis of having (or being likely to have) a better (or at least not a worse) outcome than non-intervention or alternative measures. In this section, we argue that it would be arbitrary to exclude from this balance-of-consequences calculation the alternative measures that could be pursued to address everyday atrocity. Once these are brought into view, it becomes apparent that the moral calculation used to justify pillar three military intervention is arbitrarily narrow. If the aim is to increase 'the overall global pool of protection' in a world in which 'not everybody can be protected' (Bellamy, 2015, 138), then there is no reason to exclude from this pool people who could be protected from everyday atrocity through non-military means and with more reliable prospects for success. This immanent critique is intended to expose the arbitrary and distorting narrowness of the calculations commonly used to justify military intervention. It does not imply that we accept the assumption that not everybody can be protected, nor that we consider reflection on growing and shrinking pools of protection to be an adequate way of assigning value to life and responding to people affected by atrocity crimes. 
The ICISS report that coined R2P explicitly invoked just war principles including proportionality and reasonable prospect of success. For military intervention to be justified, there must 'be a reasonable chance of success in halting or averting the suffering which has justified the intervention, with the consequences of action not likely to be worse than the consequences of inaction' (ICISS, 2001, xii). Bellamy takes this argument further, writing that 'in the world as we know it today it is not possible to protect everyone from genocide and mass atrocities all the time' (Bellamy, 2015, 138). There are, according to Bellamy, simply too many cases for us to commit to, and the resources that can be committed to protection are finite. 'The harsh reality is that not everybody can be protected' (Bellamy, 2015, 138). 'Sometimes', Bellamy continues, 'protection may be too expensive - the costs of protecting a particular population might be so high as to preclude the protection of others'. Thus, even where there is a just cause and a good probability of success, there is still a need to decide between several cases of possible intervention, and analyse which one will do more to increase humanitarian protection overall. This may mean that international action is inconsistent; some people get protected whilst others do not. But 'by protecting some people from genocide and mass atrocities, the overall global pool of protection increases’ (Bellamy, 2015, 138). On these terms, protection is ultimately about protecting as many people as possible.

If it is true that resources for protection are scarce - the huge military budgets of some states may suggest otherwise - then in a world of everyday atrocity it is difficult to sustain the claim that the pool of protection is best increased through the use of military means. There is always radical uncertainty in military intervention. It is never possible to prove decisively what would have been the case had intervention happened (or, where it did happen, had it not) (Paris, 2014, 574-575). It should come as no surprise, then, that even then Special Advisor on the Responsibility to Protect, Edward Luck (2011, 393), could do no more than report an 'unscientific feeling' that intervention had saved lives in a number of cases. Little surprise, too, that a review of studies reveals that 'there is no broad consensus' on whether military ‘interventions are effective or defensible policy to protect human rights’ (Hafner-Burton, 2014, 276). Even if more evidence were gathered, it would remain impossible to know that military intervention can do more good than harm. The case for intervention would need to calculate the expected harm - dead bodies, violated bodies, displacement and so on - over some indeterminate period of time, and measure that against the amount of relevant harm that would have occurred during the same indeterminate period of time in some alternate reality. Such analysis always amounts to guesswork in situations as complex as war and conflict, and even great advances in how one "measures" the effects of conflict will not overcome this radical 
uncertainty (Reichold and Binder, 2014). We can never be sure that military intervention "works" as a means of saving lives.

In as much as we remain focused only on the four physically violent mass atrocity crimes, the uncertainty charge cuts both ways. For example, we can point towards the negative effects of intervention in Libya and attempt to show that counterfactual analysis indicates that things would have been better had the intervention not occurred (Kuperman, 2013; HCFAC, 2016). But we cannot prove this decisively. Moreover, it is possible to point to situations - like genocide in Rwanda - where the atrocity is so severe that it is hard to imagine that military intervention could make the situation even worse. Once we break out of the narrow framework within which these consequences are calculated, however, and bring into the picture everyday atrocity, it becomes clear that there are other ways to increase 'the overall global pool of protection' (Bellamy, 2015, 138). For if there are decisions to be made on how best to increase the overall pool of protection, then these should be made not only in relation to the various mass atrocity crimes that may be happening at a given time, but also between acting to end atrocity crimes militarily and acting to stop, say, the extreme hunger experienced by 795 million of the world's people or the avoidable death of six million children under the age of five every year. At this point, it becomes apparent that talk of increasing the global pool of protection in the context of the R2P is concerned only with protecting a particular pool of people from a particular form of violation, namely large-scale assault that is direct and physical. Other "pools" of people that could be protected from other forms of violation through nonmilitary means simply do not make it into the picture. This is an arbitrary choice; it discriminates against the millions who suffer greatly but find themselves in the "wrong pool".

If this arbitrary choice is no longer made, the calculation changes. Other-defending war is extremely expensive - in financial terms, not to mention in terms of cost to lives and livelihoods. Committing apparently scarce resources by way of waging war reflects a choice; a choice that - if Bellamy is right in saying that not all people can be protected all of the time - prevents those resources from being used to fulfil the rights of others. To use the crude measure that proportionality calculi tend to boil down to: we could use the same amount of money that it would cost to wage a humanitarian war to "save" innumerable people by protecting them from a different set of wrongs, using protective means of a different sort. For example, the failure to respond adequately to the Rwandan Genocide in 1994, where 800,000 people died in 100 days of killing, is frequently invoked by proponents of military interventions. Even more people die - extremely painfully - as a result of hunger every 100 days. Moreover, it takes only 40 days for as many children under five to die, primarily from 
easily avoidable causes. Something could be done about this. It would be relatively cheap, especially when compared with the military budgets of powerful states, to save thousands, perhaps tens of thousands, of lives every day (see, i.e., WHO 2017). And steps taken to save these lives wouldn't bring with them the radical uncertainty that haunts military intervention.

Instead of proposing to use available resources in a way that will dramatically increase the overall global pool of protection, advocates of humanitarian military interventions call for protective action that, by its very nature, harms people and leads to outcomes that are radically uncertain. This action is also extremely expensive, meaning that, in Bellamy's $(2015,138)$ own logic, 'the costs of protecting a particular population might be so high as to preclude the protection of others'. If this proportionality logic is sound, it must be applied not only to the various cases of physically violent atrocity crimes. It must also - and simultaneously - be applied to the massive suffering and rights violations that take place as a matter of routine. Military intervention could be proportionate only if it were judged likely to be the most effective way of using apparently scarce resources to rescue people from any kind of atrocity. Such a judgement would also have to take into account the uncertainty that surrounds the effectiveness of military intervention, and weigh it against the strong evidence for the effectiveness of some of the measures that can be taken to address everyday atrocity.

This is not the end of the argument. For, as we shall now argue, the institutionalisation of a principle of military protection in a world of everyday atrocity and already existing intervention also gives legitimacy to military interventions performed by bad international citizens.

\section{Bad International Citizenship and Fitness to Intervene Militarily}

Protecting through military intervention is often considered a way of demonstrating "good international citizenship”. By intervening, states can demonstrate their commitment to protecting the human rights of vulnerable strangers (Wheeler and Dunne, 1998; Souter, 2016). The debate on good international citizenship in relation to military intervention, however, shares the 'relatively narrow framing' of the R2P (Souter, 2016, 796). It therefore fails to consider the implications of already existing intervention for the likely effectiveness and legitimacy of measures taken to address mass atrocity. When already existing intervention reenters the picture, it becomes clear that would-be intervening states act and fail to act in ways that render them bad international citizens. As a result, we argue, they are not fit to intervene militarily. We suggest that negative effects of intervention - seen in Kosovo and Libya - are expected products of intervention by bad international citizens, not unfortunate "accidents" 
that will be corrected as the methods of intervention are refined. In so doing, we show that the way to address mass atrocity is not to call for bad international citizens to engage militarily, but to introduce radical changes to already existing practices of intervention.

How can states demonstrate good international citizenship? According to the limited preventative toolbox currently considered in the R2P, they can do so through norm dissemination, preventive diplomacy and, as a last resort, military intervention. But there are other ways of demonstrating good international citizenship. Like the above-mentioned literature on already existing intervention, critical accounts of good international citizenship in relation to R2P have taken this to imply that states ought also to show good international citizenship through other actions, especially 'where humanitarian intervention is either imprudent or politically impossible' (Souter, 2016, 795). To this end, states should not demonstrate good international citizenship only or primarily through other-defending war, but also, for example, by granting asylum to refugees displaced as a result of atrocity crimes (Souter, 2016).

This argument does not cut deep enough. For it fails to realise that if states do not demonstrate good international citizenship by, amongst other things, providing asylum and extensive support for refugees, ceasing to sell arms used to commit human rights violations, and taking meaningful and rapid steps to tackle global environmental destruction, then they have not demonstrated the good international citizenship that ought to be required before we can even begin to contemplate the idea that their military interventions might be justified. If states are not demonstrating their willingness to protect people through means that do not also generate harm, then why should they be called upon to engage in institutionalised action that can prevent harm - if it can prevent harm at all - only by also doing harm? Or, to put the question a different way, if states are failing to provide support for those fleeing conflict and instability - according to data collected from news sources by Dutch NGO United for Intercultural Action (2018), Europe’s migrant body count since the early 1990s is 34,361 and rising - what reason do we have to think that they will protect people responsibly when they do so using military means? If states are continuously demonstrating that they are failing to protect the rights of citizens elsewhere and migrants and refugees on their land, then they are bad international citizens who are not fit to use military means in order to protect.

Adherents of military intervention have a ready response. We cannot expect acts of bad international citizenship - such as arms trading, attempts to stoke tension and maintaining debtor-creditor relations that sustain global poverty - to go away overnight. Whilst these acts are (or are not) being addressed, mass atrocities will continue to occur, and something ought 
to be done about them in the meantime. Surely one wouldn't want to stop those with sufficient material capacity from attempting to stop mass atrocities only because they have otherwise failed to demonstrate good international citizenship? As we ourselves said earlier, it may be perfectly understandable for someone on the receiving end of atrocity crimes to ask for protection even from actors who are upholding conditions that contributed to the emergence of the crisis. Should we not therefore work within 'the realm of the imminently possible' (Bellamy, 2015, 103), recognising that - for now at least - states will take measures to improve responses to mass atrocity crimes only where they are also motivated by selfish interests? Although 'the motivations states have for supporting R2P may be driven by interests that have little or nothing to do with responsible sovereignty', they may, the argument continues, nonetheless 'contribute to humanitarian outcomes and lead to the further development of the R2P’ (Dunne and Gelber, 2015, 227).

Why, then, are we nonetheless claiming that when states are bad international citizens on account of already existing forms of (non-military) intervention, they are not fit to intervene militarily? Unlike Nili's argument for disintervention, our claim is not based on the priority of negative duties. Nor is it solely a claim about the priority of positive duties that can be fulfilled without doing the extensive harm characteristic of military intervention. It is also a claim about the likely effectiveness of intervention by actors that show their callousness through their arms sales, their treatment of migrants and so on. Interventions conducted by bad international citizens are likely to have negative consequences. The view that, despite being based on national interests, interventions might make a positive contribution to humanitarian outcomes is based on a misjudgement of the extent to which the bad international citizenship of actors plays out in practices of intervention. As Graubart $(2013,78)$ argues, it treats national interests as 'relatively innocuous' - as preserving stability and stemming the tide of refugees. When we bring already existing intervention back in, however, we see that these interests are far from innocuous. Take, for instance, the USA and UK - two states that led the way in the interventions in Kosovo and Libya. These states sell vast amounts of arms, including to Saudi Arabia, in full knowledge that they are being used on civilians in Yemen (Mohamed, 2017; Wearing, 2016). They are amongst the highest polluters, and hence amongst the most significant contributors to so-called “climate wars” (Welzer, 2017). In the case of the USA, they have also withdrawn from a landmark international climate change agreement. In addition, a Pentagon-sponsored, bipartisan task force report lists as reasons to use force not only the prevention of genocide, but also access to resources, the extension of market-friendly global economic integration, and the prevention of rival hegemons (USCNS, 2000). Relatedly, with 
reference to arms sales to post-war Libya and Iraq, UK Junior Minister Robert Howarth said: 'We liberated the Iraqis from a tyrant, we liberated Libya from a tyrant, frankly, I want to see UK business benefit from the liberation we give to their people' (Speech to Conservative Party Conference, cited in BBC, 2011). These stated interests have been furthered through action: the renewal of arms sales to an unstable Libya mere months after the "end" of civil war, and a massive US military projection which includes 'expanding US military bases' across the world and 'setting up regional command facilities for each part of the world' (Graubart, 2013, 78).

What these states are - their bad international citizenship and the self-interests that they pursue through it - doesn't only reproduce everyday atrocity through already existing intervention. It also shapes purportedly humanitarian and protective interventions. In Kosovo, the US showed little interest in the Rambouillet talks - held when there were real hopes of a peace deal in early 1999 (IICK, 2000). And there was minimal condemnation of war crimes carried out by Kosovars under the cover of NATO air support. Such conduct cannot be explained with reference to humanitarian protection. If we instead think of the mission as giving a renewed mandate to NATO and, as per the statement of US interests in the aforementioned Pentagon report, extending global economic integration along market-friendly lines, the war starts to make sense (Graubart, 2013). Indeed, John Norris (2005, xxiii), a prominent state department official at the time, suggested that 'it was Yugoslavia's resistance to the broader trends of political and economic reform - not the plight of Kosovar Albanians that best explains NATO’s wars'. Turning to Libya, states that supported the intervention notably South Africa - and states that abstained, including Brazil and China, were critical of the way in which the intervention was conducted. Specifically, they accused NATO of "mission creep"; of going beyond their mandate of protection and pursuing regime change, even where it was not the best means to protect (Zuma, 2011; Viotti, 2011). NATO shunned African Union peace talks even when there was a chance of a breakthrough, and made clear to the rebels that they would receive support regardless of whether they engaged in talks (de Waal, 2013). The interests and moral character of the interveners, far from being compatible with a humanitarian outcome, thus resulted - unsurprisingly - in an intervention with inhumanitarian outcomes. NATO stood by as the rebels committed rights violations of their own, including in Tawergha - a town that was ethnically cleansed by rebels who, through killing, torture and displacement, forced black Libyans and migrants to leave on the basis of a mistaken assumption that they were Quaddafi-supporting mercenaries. Human Rights Watch (2012) reported that abuses around Tawergha and Misrata 'appear to be so widespread and systematic that they may amount to crimes against humanity'. Such stark racial and ethnic violence had 
not occurred in Libya under Quaddafi's rule, repressive though it was (OHCHR, 2012). The death toll in Libya rose substantially after the NATO intervention (Kuperman, 2013). Moreover, instability in Libya allowed arms to spread across the region to Mali and beyond, and has left a legacy of state failure that continues to this day (HCFAC, 2016). The character of the interveners - their having interests and agendas that go far beyond protection - thus led to an intervention that was a 'catastrophic failure' (Milne, 2011).

With this political context in mind, let us return to Fabre's analogy of a child drowning in water. This analogy fundamentally distorts the political context of intervention. It is not the case that interveners have 'negligently' pushed someone into a pond (Fabre, 2012, 190, emphasis added). Nor have they stumbled upon a child drowning. Rather, would-be interveners are systematically, and on the basis of known foreign policy agendas, engaging in action that stokes conflict. They also have agendas - such as military projection and opening markets that ensure that they carry out interventions in ways that end up having extremely harmful consequences. These agendas are aided and abetted by, and are not separate from, their military interventions. Indeed, the very military might that renders such actors able - in the limited sense of having the requisite material capacity - to engage in intervention stems precisely from their military projection, the resources they gain through uneven forms of trade, and the destruction of the environment that sustains military and monetary projection. Once we abandon abstract and distorting pond analogies and look at real, existing examples, we see that the moral character of states has a decisive influence on how interventions play out. A world rife with already existing intervention is thus more complex than the pond analogy suggests; there is a deep connection between a large number of "murderers" (and accomplices) and an even larger number of children who are constantly drowning - indeed being drowned - in various ponds.

Inhumanitarian effects of intervention in Kosovo and Libya are not just accidents or miscalculations that will be corrected as relevant parties learn from experience. Rather, failure to protect in such cases is to be expected. After all, such interventions are carried out by actors already engaged in damaging practices of intervention. For everyday atrocity and the crimes of genocide, ethnic cleansing, war crimes and crimes against humanity to be addressed, these agents need to stop being bad international citizens and change their existing practices. This is not to say that once they no longer systematically violate their duties, military intervention becomes “fair game”. We simply don't know what the world would look like in the absence of everyday atrocity and harmful practices of already existing intervention. It may be the case that the four atrocity crimes would no longer arise. And if they did, it may be the case that military 
intervention would still have extremely harmful consequences. The point is that in this world, the states often called on to intervene are not fit for purpose. When states are bad international citizens on account of the way in which they contribute to (and fail to address) everyday atrocity, refuse to protect people fleeing from conflict, and help produce mass atrocities, they are not fit to engage in military intervention in order to protect people. This does not only mean, for instance, that France were not fit to intervene in Rwanda on account of their arms sales to Rwanda, or that the UK are not fit to intervene in Syria on account of their failure adequately to support refugees displaced by the Syrian conflict. It is to say that such actors are not fit for the purpose of humanitarian military intervention full stop. Their moral character is such that they cannot be expected to protect responsibly. Rather, their military interventions can be expected, for reasons outlined above, to have inhumanitarian consequences.

If we are right, it may be the case that no states are fit to intervene militarily. Our argument would then imply that pillar three intervention cannot be justified. Have we gone too far? We cannot expect actors to stop being impure in the near future, perhaps not even in the distant future. Even if we are right in saying that interventions by such actors will have inhumanitarian and unprotective outcomes, and that this is usually sufficient reason to object to their engagement in pillar three interventions, some may still think that there is a residual case for intervention. Think, here, of extraordinary and extreme cases like the Rwandan genocide, where hundreds of thousands of people were slaughtered over a matter of weeks. In such extreme circumstances, wouldn't the inhumanitarian and unprotective effects of interventions launched by bad international citizens be better than, or at least not as bad as, what actually transpired? And, if this is the case, is it not right to intervene militarily, albeit only in those absolutely extraordinary circumstances? Is intervention still 'justified as if it were an exception to a general rule, made necessary by the urgency or extremity of a particular case'

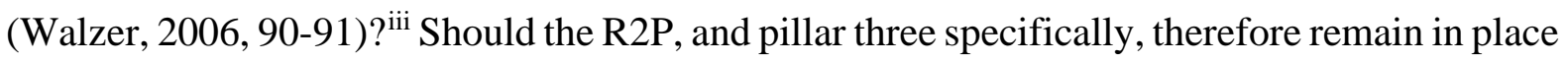
whilst deeper changes to already existing interventions are pursued, as a stop-gap measure for addressing the very worst cases of atrocity when the only actors in a position to address atrocity remain impure and unfit?

Two issues are at stake here. The first is whether intervention in such exceptional circumstances is justified or morally right. And the second concerns whether, in light of this residual case for intervention, the R2P should be kept in place to facilitate responses to these exceptional cases. Addressing the first issue would take us deep into fundamental issues in just war thinking and require a paper in its own right. Whilst we cannot examine this here, it is worth noting that two assumptions underlie the argument that military interventions launched 
by bad international citizens can be morally justified by virtue of the extremity of the situation. The first is that in these situations there is a binary choice to be made, a choice in which military intervention is the only alternative to extraordinary horrors. This binaristic framing hides from view various other, non-violent modes of protection that might be pursued (see, i.e., Jackson, 2018; Julian and Gasser, 2018; Wallace, 2016); non-violent options that, if what we said above about proportionality calculations is right, would also have to take into account all the things that could be done to address everyday atrocity. The second assumption is that this binary choice is one in which one of the options is morally justified and thus right. This assumption rules out the possibility that the situation, so conceived, is one in which it is not possible to do the right thing. If in this situation one were to come down on the side of intervention by bad international citizens - with all the inhumanitarian and unprotective practices that come with it - over the horrors that would arise in its absence, that does not necessarily mean that intervention is right or justified (see Neu, 2017). It may be that all we can say, morally speaking, is that we have the duty to prevent these situations from occurring, that we are currently failing to meet this duty, and that the R2P, by failing to recognise the already existing interventions that contribute to the emergence of atrocity crimes, does not adequately address this failure (see Dunford and Neu, 2019).

We recognise, though, that readers may disagree about this and think that the exceptionality of a case like Rwanda makes military intervention right. Or they may, in a situation of despair, come down on the side of intervention by bad international citizens despite being reluctant to call it "right”. It does not follow from this, however, that the R2P should be kept in place. For accepting intervention in an exceptional case does not mean accepting that such a response should be institutionalised through new norms. As we shall argue in the next section, the R2P is a regressive norm that serves to legitimise a moralistic form of militarism which hinders, rather than helps, attempts to address mass atrocity.

\section{Legitimising Moralistic Militarism}

Supporters of R2P often ask what would be left if, on the basis of arguments such as the ones above, we got rid of the R2P. Would 'winding back the rules' not, as Bellamy puts it, wind 'back restraints on organised violence', making 'elimination a yet more remote ambition'? (Bellamy, 2015, 109) Is the R2P not at least something that encourages states to care about victims of atrocities beyond their borders; something that can help address those very worst cases of atrocity while we push for deeper changes to practices of bad international citizenship? It also, Bellamy $(2015,111)$ argues, 'points toward a world different to the one we have today' 
- to a world in which there is no longer a need to engage militarily to protect people. This is because it is a norm that generates moral change in states and their representatives, forcing them to recognise their responsibilities and allowing us, over time, to demand more from them. Are critics not undermining the only bulwark against a world in which states are free to do to their citizens what they please, and a world in which the international community stands callously aside in the face of humanitarian crises?

In this section, we turn from pillar three intervention to the R2P more broadly, arguing that, far from being a positive force for change, it legitimises a moralistic form of militarism. By militarism, here, we refer to 'a set of attitudes and social practices which regards war and the preparation for war as normal and desirable social activity’ (Mann, 1987, 35). And by moralistic militarism, we mean a militarism in which 'war and its attendant industries must be squared with normative commitments', principally, spreading humanitarian protection globally (Basham, 2018, 33). Linking our focus on already existing intervention to feminist anti-militarist scholarship, we argue that the problem with the R2P is not only that its own consequentialist calculations are arbitrarily narrow and that it fails to recognise the problems associated with interventions launched by bad international citizens. It also frames the way we think - and fail to think - about protection. In hiding from view already existing interventions and simultaneously justifying military intervention, the R2P contributes to a climate in which violence for the alleged purpose or protection comes to be perceived as just, civilised and virtuous. This perception forms part of a general amnesia about the harmful effects of current practices, and about how these practices need to be radically altered to address atrocity. Thus, even if one were to think that there are exceptional cases that warrant military intervention, it would be a mistake to support the R2P in order to facilitate responses to those cases. For so doing would reinforce, not challenge, a militaristic moral climate that blinds us to the deeper changes that need to be made in order to respond adequately to atrocity.

Our claim that the R2P contributes to a militaristic moral climate does not imply that R2P acts as a "Trojan horse" or "right of passage” which, in a direct and straightforward way, makes it easier for states to intervene in the affairs of other states. Given that the R2P does not change the international order structurally, it remains the case that Russia and/or China are likely to veto proposals to use military means when they suspect that the interests of "Western" powers are behind calls for intervention, much as the USA, France and/or the UK are likely to veto if they deem, say, Russian interests to be driving calls for intervention (see Bellamy, 2015, 112-133). But the R2P is not mere 'sound and fury signifying nothing'; meaningless talk that does not ultimately change anything (Hehir, 2010). By affecting 'the moral attitudes of people, 
the moral climate within which direct consequences are characterised and assessed', it 'wreak[s] its damage in ways other than straightforwardly causal ones' (Brecher, 1987, 184). In this regard, we agree with Bellamy's claim that the R2P does have some normative force. Contra Bellamy, however, this is not a force that improves the international prevention of, and response to, atrocity. After all, as reported by UN Secretary General António Guterres, 'the number of civilians subjected to atrocity crimes ... has increased significantly over the past few years' (UN, 2017). Bellamy's presumption that the R2P is making things better is reflective of a tendency to see norms as inherently progressive, and fails to recognise the way in which even 'seemingly progressive' norms can contain 'the seeds' of their 'own complicity in broader systems of preparation for war and violence’ (Stavrianakis, 2016, 844). Ignored here is the way in which norms can also 'provide an instrument of legitimation - albeit imperfect, incomplete, and fiercely contested' (Khalili, 2012, 67).

The R2P provides such an instrument of legitimation. By design, it legitimates military action in the name of moral values: war serves to protect individuals from mass atrocity crimes, from the 'predations of brutish rulers intent on butchering their population' (Thakur, 2013, 69). In focusing on problems that emerge over there, internally to Thakur's $(2013,62)$ 'zones of danger', however, the R2P pays attention only to the violence of "barbaric" others, hiding from view the ordinary and everyday violence of would-be saviours. The moral climate it helps create is one in which military interventions are assessed and praised, on a case-by-case basis, as civilised, benign and virtuous actions that serve to protect the victims of rogues around the world. Interventions are not assessed as part of broader pattern in which military protection occurs over and above already existing practices of intervention, and can serve to uphold and reproduce power structures that create the conditions in which atrocity thrives. It then becomes possible for interveners to be presented as virtuous and agonised heroes willing to risk their lives in war - and needing to be constantly prepared to do so - in order to protect distant strangers from falling victim to atrocity crimes. The R2P thus works to normalise a perception according to which “doing good”, pursuing interests, maintaining large military budgets and going to war can be happily reconciled; where the institutionalisation of humanitarian warfare is an appropriate method to increase the "pool of protection". It pretends that the problem of mass atrocity can be fixed, or at least ameliorated, without raising questions about the bad citizenship of would-be saviours. Indeed, there is an underlying belief here that virtue and militarism can somehow be made to work together to produce a better world and enable wouldbe saviours to become better international citizens over time. For reasons outlined above, this is a dangerous illusion. A moral climate in which this illusion becomes accepted wisdom is not 
one in which the complex and multifaceted problem of mass atrocity can be understood, let alone addressed. It is only in such a climate, moreover, that the militarism of those stoking the flames of crisis can come to be regarded - mistakenly - as morally legitimate and likely to be effective.

Those whose aims are to limit atrocity and increase protection thus need to turn in a different direction. As feminist scholars and activists have argued, limiting war and protecting people from mass atrocities requires leaving behind 'militarist logics that value hierarchical orders and the promotion of limited violence to ensure peace' (Wibben, 2018, 140; see also O’Connell, 2010). Thus, rather than add to the R2P a focus on Jus ante Bellum or refugee protection, responding adequately to already existing intervention and everyday atrocity means shifting towards a different framework - one that is not militaristic, and one that is rooted in an analysis of, and challenge to, the way in which bad would-be saviours stoke the very humanitarian crises that elicit calls for a response. It requires an approach that is contra bellum, not an extension of a militaristic framework to include Jus ante Bellum.

\section{Conclusion}

Existing literature has started to recognise the way in which the R2P ignores already existing intervention and everyday atrocity. But it has not sufficiently explored their implications for the legitimacy and likely effectiveness of pillar three intervention. So far, the approach has been to add to the R2P a focus on wider structural injustices or refugee support (Brown \& Bohm, 2016; Souter, 2016). This add-on approach says that if you accept military intervention, you should also reflect on and address already existing intervention, everyday atrocity, lack of support for people displaced through war, and so on. As we have argued, this approach takes us in the wrong direction. If actors are already responsible for this (everyday atrocity, already existing intervention), then they are not fit to do that (military intervention). Hence, where addon approaches leave military intervention untouched, we have shown that everyday atrocity and already existing intervention have significant ramifications for pillar three and for the R2P more broadly. First, they complicate the proportionality calculation which forms a key part of defences of military intervention. Second, they show that would-be interveners are bad international citizens who are not fit for the purpose of military intervention. Third and finally, by forgetting the everyday violence of already existing intervention and everyday atrocity while simultaneously calling for military intervention, the R2P serves to legitimise a moralistic form of militarism. 
Our three arguments suggest that it is a mistake to support the development of the R2P. Far from offering protection from mass atrocity and being the vanguard of a progressive change toward a less violent world, the R2P serves to legitimise a moralistic form of militarism. Far from limiting, preventing and appropriately responding to mass atrocities, the R2P gives a veneer of legitimacy to military interventions performed by states that are already engaged in damaging forms of political and economic intervention. And while focus is placed narrowly on military intervention when crises have already emerged, while a chorus keeps emerging insisting that actors - the "West” especially - cease their "hand-wringing” and "do something”, attention slips away from the deep changes that need to be made to stop these situations emerging. Moving forward does not mean adding a focus on wider structural injustices, leaving the R2P otherwise unchanged. It requires stepping aside from the R2P and focusing on nonmilitarist alternatives, including the rich array of changes to already existing intervention that would both reduce the atrocity we witness every day and make for a world less conducive to genocide, war crimes, ethnic cleansing and crimes against humanity.

\section{Bibliography}

Anievas, A. and Nişancioğlu, K. (2016) How the West Came to Rule. London: Pluto Press. Basham, V. M. (2018) ‘Liberal Militarism as Insecurity, Desire and Ambivalence: Gender, Race and the Everyday Geopolitics of War’. Security Dialogue 49(1-2): 32-43 BBC (2011) ‘A Point of View: Why Euphemism is Integral to Modern Warfare’, 29 October 2011. Available at: https://www.bbc.co.uk/news/magazine-15478001 (accessed 20 July 2018).

Bellamy, A. (2015) The Responsibility to Protect: A Defence. Oxford: Oxford University Press.

Boone, C. (2014) Property and Political Order in Africa. Cambridge: Cambridge University Press.

Brecher, B. (1987) 'Surrogacy, Liberal Individualism and the Moral Climate'. Royal Institute of Philosophy Supplements 22: 183-197.

Brown, G. W. and Bohm, A. (2016) 'Introducing Jus ante Bellum as a Cosmopolitan Approach to Humanitarian Intervention'. European Journal of International Relations 22(4): 897-919.

Campaign Against the Arms Trade (CAAT) (2013) 'UK Arms Sales to Gaddafi's Libya'. Available at: https://www.caat.org.uk/resources/countries/libya/uk-gaddafi (accessed 01 November 2017). 
Collier, P; Elliott, V. L.; Hegre, H.; Hoeffler, A.; Reynal-Querol, M.; and Sambanis, N. (2003) Breaking the Conflict Trap: Civil War and Development Policy. Washington, DC: World Bank and Oxford University Press.

De Waal, A. (2013) 'African Roles in the Libyan Conflict of 2011'. International Affairs 89(2): 365-379.

Dunford, R. and Neu, M. (2019) Just War and the Responsibility to Protect: A Critique. London: Zed Books.

Engle, K. (2007) ““Calling in the Troops”: The Uneasy Relationship among Women’s Rights, Human Rights, and Humanitarian Intervention’. Harvard Human Rights Journal 20: 189-226 Evans, G. J. (2009) The Responsibility to Protect: Ending Mass Atrocity Crimes Once and for All. Washington, D.C.: Brookings Institution Press.

Fabre, C. (2012) Cosmopolitan War. Oxford: Oxford University Press.

Fruchart, D.; Holtom, P.; and Wezeman, S. T. (2007) United Nations Arms Embargoes: Their Impact on Arms Flow and Target Behaviour. Uppsala: Uppsala University.

Galeano, E. (1997) Open Veins of Latin America. New York, NY: Monthly Review Press.

Global Financial Integrity (2015) 'Financial Flows and Tax Havens: Combining to Limit the Lives of Billions of People'. Available at: http://www.gfintegrity.org/wpcontent/uploads/2016/12/Financial_Flows-final.pdf (accessed 30 July 2018).

Graubart, J. (2013) 'R2P and Pragmatic Liberal Interventionism: Values in the Service of Interests'. Human Rights Quarterly 35(1): 69-90.

Hafner-Burton, E. M. (2014) 'A Social Science of Human Rights'. Journal of Peace Research 51(2): 273-286.

Heathcote, G. (2014) 'Feminist Perspectives on the Law on the Use of Force', in Weller, M. (ed.) The Oxford Handbook of the Use of Force in International Law. Oxford: Oxford University Press.

Hehir, Aidan. (2010) 'The Responsibility to Protect: "Sound and Fury Signifying Nothing”?' International Relations 24(2): 218-239.

Hickel, J. (2013) 'The Donors’ Dilemma' - Aid in Reverse: How Poor Countries Develop Rich Countries. Global Policy Journal. Available at: https://www.globalpolicyjournal.com/blog/12/12/2013/donors\%E2\%80\%99-dilemma-aidreverse-how-poor-countries-develop-rich-countries (accessed 20 July 2018). Hickel, J. (2017) The Divide: A Brief Guide to Global Inequality and Its Solutions. Cornerstone Digital. 
House of Commons Foreign Affairs Committee (HCFAC) (2016) 'Libya: Examination of Intervention and Collapse and the UK's Future Policy Options'. UK House of Commons. Available at:

https://www.publications.parliament.uk/pa/cm201617/cmselect/cmfaff/119/119.pdf (accessed 21 June 2018).

Human Rights Watch (2012) 'Libya: Wake-Up Call to Misrata’s Leaders: Torture, Killings May Amount to Crimes Against Humanity'. Available at:

https://www.hrw.org/news/2012/04/08/libya-wake-call-misratas-leaders (accessed 21 March 2018).

Hunger and World Poverty (2018) Available at: http://www.poverty.com (accessed 27 June 2018).

Independent International Commission on Kosovo (IICK) (2000) The Kosovo Report: Conflict, International Response, Lessons Learned. Oxford: Oxford University Press. International Commission on Intervention and State Sovereignty (ICISS) (2001) The Responsibility to Protect. Canada: International Development Research Centre. Jackson, R. (2018) 'Pacifism: the Anatomy of a Subjugated Knowledge. Critical Studies on Security 6(2): 160-175.

Julian, R. and Gasser, R. (2018) 'Soldiers, Civilians and Peacekeeping - Evidence and False Assumptions’. International Peacekeeping 26(1): 22-54.

Khalili, L. (2013) Time in the Shadows: Confinement in Counterinsurgencies. Stanford, California: Stanford University Press.

Landrigan, P. J. et al. (2018) 'The Lancet Commission on Pollution and Health'. The Lancet 391(10119): 462-512.

Luck, E. C. (2011) 'The Responsibility to Protect: The First Decade’. Global Responsibility to Protect 3(4): 387-399.

Mamdani, M. (2010) ‘Responsibility to Protect or Right to Punish?’ Journal of Intervention and Statebuilding 4(1): 53-67.

Mann, M. (1987) 'The Roots and Contradictions of Modern Militarism'. New Left Review I(162): 35-50.

Milne, S. (2011) 'If the Libyan War was about Saving Lives, it was a Catastrophic Failure'. The Guardian, 26 October 2011. Available at:

https://www.theguardian.com/commentisfree/2011/oct/26/libya-war-saving-livescatastrophic-failure (accessed 21 July 2018). 
Moon, B. K. (2007) A Climate Culprit in Darfur. Available at:

http://www.washingtonpost.com/wp-

dyn/content/article/2007/06/15/AR2007061501857.html??noredirect=on, (accessed 20 July 2018).

Naiman, R. (2015) 'Syria’, in The Wikileaks Files. London: Verso.

Neu, M. (2017) Just Liberal Violence: Sweatshops, Torture, War. London: Rowman and Littlefield International.

Nili, S. (2011) ‘Humanitarian Disintervention’. Journal of Global Ethics 7(1): 33-46.

Norris, J. (2005) Collision Course. Westport: Praeger.

O’Connell, M. E. (2010) 'Responsibility to Peace: A Critique of R2P'. Journal of

Intervention and Statebuilding 4(1): 39-52.

Orford, A. (1997) 'Locating the International: Military and Monetary Interventions after the Cold War’. Harvard International Law Journal 38(2): 443-485.

Paris, R. (2014) 'The "Responsibility to Protect” and the Structural Problems of Preventive Humanitarian Intervention’. International Peacekeeping 21(5): 569-603.

Pourmokhtari, N. (2013) 'A Postcolonial Critique of State Sovereignty in IR: the

Contradictory Legacy of a “West-centric” Discipline’. Third World Quarterly 34(10): 17671793.

Power, S. (2001) 'Bystanders to Genocide: Why the United States Let the Rwandan Tragedy Happen’. September 2001, The Atlantic.

Reichold, U. and Binder, A. (2014) 'The Metrics and Ethics of Protecting Civilians'. Global Responsibility to Protect 6(2): 206-226.

Simpson, E. (2016) 'Stop the Hand-Wringing about Aleppo'. Foreign Affairs. Available at: https://foreignpolicy.com/2016/12/19/stop-the-hand-wringing-about-aleppo (accessed 20 July 2018).

Souter, J. (2016) 'Good International Citizenship and Special Responsibilities to Protect Refugees'. The British Journal of Politics and International Relations 18(4): 795-811. Stavrianakis, A. (2016) 'Legitimising Liberal Militarism: Politics, Law and War in the Arms Trade Treaty'. Third World Quarterly 37(5): 840-865.

Thakur, R. (2013) 'R2P after Libya and Syria: Engaging Emerging Powers'. The Washington Quarterly 36(2): 61-76.

Tisdall, S. (2018) ‘After Douma, the West’s Response to Syria’s Regime Must Be Military. The Guardian, 09 April 2019. Available at: 
https://www.theguardian.com/commentisfree/2018/apr/09/douma-syria-regime-bashar-alassad-murder-civilians?CMP=share_btn_fb (accessed 20 July 2018).

United for Intercultural Action (2018) 'The List'. Available at:

https://uploads.guim.co.uk/2018/06/19/TheList.pdf (accessed 30 July 2018).

United Nations (UN) (2014) 'Fulfilling our Collective Responsibility: International

Assistance and the Responsibility to Protect: Report of the Secretary General'. Geneva:

United Nations, UN Doc A/68/947-S/2014/449.

United Nations (UN) (2015) ‘A Vital and Enduring Commitment: Implementing the

Responsibility to Protect: Report of the Secretary General'. Geneva: United Nations, UN Doc A/69/981-S/2015/500.

United Nations Office of the High Commissioner for Human Rights (OHCHR) (2012)

Human Rights Council: Report of the International Commission of Inquiry on Libya'.

Available at:

http://www.ohchr.org/Documents/HRBodies/HRCouncil/RegularSession/Session19/A.HRC. 19.68.pdf (accessed 20 July 2018).

US Commission on National Security/21 $1^{\text {st }}$ Century Hart-Rudman Commission (USCNS)

(2000) 'Seeking a National Strategy: A Concert for Preserving Security and Promoting

Freedom’. Available at: http://govinfo.library.unt.edu/nssg/PhaseII.pdf (accessed 27 June 2018).

Viotti, M. L. R (2011) ‘Statement by Ambassador Maria Luiza Ribeiro Viotti Permanent Representative of Brazil to the United Nations', 10 May 2011. Available at: http://responsibilitytoprotect.org/brazil.pdf (accessed 28 June 2018).

Wallace, M. (2016) Security Without Weapons: Rethinking Violence, Nonviolent Action, and Civilian Protection. London: Routledge.

Walzer, M. (2006) Just and Unjust Wars: A Moral Argument with Historical Illustrations. Revised ed. New York: Basic Books.

Wearing, D. (2016) 'A Shameful Relationship: UK Complicity in Saudi State Violence', London: Campaign Against the Arms Trade. Available at: https://www.caat.org.uk/campaigns/stop-arming-saudi/a-shameful-relationship.pdf, (accessed 01 November 2011).

Welzer, Harald. (2017) Climate Wars: What People Will Be Killed For in the 21st Century. Cambridge: Polity.

Wheeler, N. J. and Dunne, T. (1998) 'Good International Citizenship: A Third Way for British Foreign Policy’. International Affairs 74(4): 847-870. 
Wibben, A. T. R. (2018) 'Why we Need to Study (US) Militarism: a Critical Feminist Lens'. Security Dialogue 49(1-2): 136-148.

Wintour, P. (2016) 'British MPs Bear Some Blame for Aleppo Tragedy, says George Osborne', The Guardian. Available at:

https://www.theguardian.com/world/2016/dec/13/aleppo-syria-commons-debate-georgeosborne (accessed 20 July 2018).

World Health Organization (WHO) (2017) '10 Facts on the State of Global Health’. Available at: http://www.who.int/features/factfiles/global_burden/en/ (accessed 31 October 2017).

Zuma, J. (2011) 'Statement by President Jacob Zuma on the Occasion of the UN Security Council Summit Debate’, 12 January 2012. Available at:

http://www.newzimbabwe.com/opinion-6919-

Zumas+Security+Council+Debate+speech/opinion.aspx (accessed 19 February 2018).

\footnotetext{
${ }^{\mathrm{i}}$ We recognise that this departs from an understanding, common in debates on military intervention, according to which "intervention" is something that takes place without the consent of the state in which intervention takes place, and is in that sense in violation of its sovereignty (as the right to exclusive control over territory). Some of our examples - arms trading for instance - involve consensual relations between states, whilst others, notably contribution to environmental destruction, can involve action at a distance. Our use is consistent, though, with broader meanings of intervention as an action or set of actions that makes a relevant difference (e.g., a medical intervention). In this respect, we refer to those international actions that make a difference in contributing to the emergence of atrocity crimes. The broad use of the term adopted here serves an important purpose in departing from the narrow framing of "intervention" in debates on military intervention.

ii Some estimates, informed by a Lancet study, suggest that a child dies a hunger-related death every 10 seconds. We have taken a relatively conservative estimate for the number of people (children and adults) who die from hunger each year from Hunger and World Poverty (2018), who draw on data from the UN World Food Program, Oxfam and Unicef.

iii The general rule to which Walzer refers is respect for community boundaries. We refer to a different rule here, according to which military intervention by bad international citizens is neither legitimate nor likely to be effective.
} 